\title{
La figure et le poème dans Shakespeare à travers La Tempête
}

Henri Meschonnic

\section{OpenEdition}

\section{Journals}

Édition électronique

URL : http://journals.openedition.org/shakespeare/1237

DOI : 10.4000/shakespeare.1237

ISSN : 2271-6424

Éditeur

Société Française Shakespeare

Édition imprimée

Date de publication : 1 novembre 1992

Pagination : 125-141

\section{Référence électronique}

Henri Meschonnic, "La figure et le poème dans Shakespeare à travers La Tempête », Actes des congrès de la Société française Shakespeare [En ligne], 10 | 1992, mis en ligne le 01 janvier 2007, consulté le 02 mai 2019. URL : http://journals.openedition.org/shakespeare/1237 ; DOI : 10.4000/shakespeare.1237

Ce document a été généré automatiquement le 2 mai 2019.

(C) SFS 


\section{La figure et le poème dans Shakespeare à travers La Tempête}

Henri Meschonnic 